Marquette University

e-Publications@Marquette

Philosophy Faculty Research and Publications

Philosophy, Department of

$11-1-2009$

\title{
Using Rights to Counter "Gender-Specific" Wrongs
}

Theresa Tobin

Marquette University, theresa.tobin@marquette.edu

Accepted version. Human Rights Review, Vol. 10, No. 4 (November 2009): 521-530. DOI. (C) 2009 Springer. Used with permission.

Shareable Link. Provided by the Springer Nature SharedIt content-sharing initiative. 


\title{
Using Rights to Counter "Gender- Specific" Wrongs
}

\author{
Theresa W. Tobin \\ Department of Philosophy, Marquette University \\ Milwaukee, WI
}

One popular strategy of opposition to practices of female genital cutting (FCG) is rooted in the global feminist movement. Arguing that women's rights are human rights, global feminists contend that practices of FGC are a culturally specific manifestation of gender-based oppression that violates a number of rights. Many African feminists resist a women's rights approach. They argue that by focusing on gender as the primary axis of oppression affecting the African communities where FGC occurs, a women's rights approach has misrepresented African women as passive victims who need to be rescued from African men and has obscured the role of certain international institutions that have perpetuated the oppression of African women. In this paper, I defend these critiques by arguing that the use of a women's rights framework to combat practices of female genital cutting among African communities has often been practically ineffective and morally inappropriate.

\section{Introduction}

One of the most popular strategies of opposition to practices of female genital cutting (FGC) is rooted in the global feminist movement, which construes patriarchy as the root cause of women's oppression around the globe. Arguing that women's rights are human rights, global feminists contend that practices of FGC are a culturally specific manifestation of patriarchy or gender-based oppression that violates a number of rights including the rights of the child, the right to bodily and sexual integrity, and the right to freedom from torture and 
violence. Many African feminists have been highly critical of the global feminist discourse on FGC for its tendency to characterize these practices as a "symptom of female victimization by male authority and an attempt to control women's sexuality" (Abursharaf 2006). They charge that, by focusing on gender as the primary or sole axis of oppression affecting the African communities where FGC occurs, global feminists have (mis) represented African women as passive helpless victims who need to be rescued from African men in positions of power who are trying to control them. Moreover, some African feminists argue that a human rights approach fails to identify accurately the nature of the moral violations FGC inflicts and obscures the role of certain state actors and international institutions both historically and at present that have been involved in perpetuating these practices.

I agree that the way human rights have been constructed and used to combat practices of FGC and other gender-specific wrongs within African communities has often been practically ineffective and morally inappropriate. In the first part of this paper, I discuss these critiques in a bit more detail and then illustrate their force by examining practices of FGC among the Maasai of Kenya and Tanzania. I then conclude with some very general suggestions for how we might reconsider the relationship between gender and rights in order to facilitate a more practically effective and morally appropriate use of human rights to combat the oppression women around the globe.

\section{Women's Rights as Human Rights}

It is now widely recognized that early rights documents, such as the United Nation's Universal Declaration of Human Rights, failed to provide adequate protection for women. The concept of rights employed in such documents came out of an enlightenment understanding of rights that rested on a fairly rigid public/private distinction (Okin 1998). On this model, the scope of rights protected against abuses within the public realm, the realm of work and citizenship, and protected from external interference in the private realm of family, religion, and culture. The problem of course is that a vast majority of women around the world spend a vast majority of their lives and experience some of the worst forms of abuse within the so-called private realm. By defining the family, religion, and culture outside of the scope of rights, early human rights documents made many of the most egregious violations against women at best invisible

Human Rights Review, Vol. 10, No. 4 (November 2009): pg. 521-530. DOI. This article is (C) Springer and permission has been granted for this version to appear in e-Publications@Marquette. Springer does not grant permission for this article to be further copied/distributed or hosted elsewhere without the express permission from Springer. 
and at worst justifiable by appeals to respect for cultural and religious differences. ${ }^{1}$

In the decades following, the Committee on the Elimination of Discrimination Against Women, a global feminist movement, emerged that began theorizing rights from the lives of women, culminating in the 1995 Beijing Declaration and Platform for Action and continuing today (Covenant for the Millennium 1996; Morgan 1984; Peters and Wolper 1995; Bunch 1999; Okin 1999). The Beijing platform articulated a new conception of rights that brought previously protected realms of family, religion, and culture under scrutiny and named specific practices, such as FGC, as human rights abuses. No doubt the Beijing Platform and other international efforts have made important strides in making the rights of women visible and in forcing the international community to challenge those who hide behind respect for cultural and religious differences in order to justify abuse of and discrimination against women. Nonetheless, the global feminist movement to make women's rights human rights has prompted heated and at times bitter debate. One pocket of continued resistance comes from African scholars and activists working to address practices of FGC occurring within African communities (Abusharaf 2006; Nnaemeka 2005). These women condemn FGC and seek eradication efforts. They do not dispute the moral status of these practices but rather the global feminist discourse surrounding these practices. As Obioma Nnaemeka states:

Female circumcision has been condemned as a "torture" or "degrading treatment" that lacks any "respect for the dignity" of women and girls. And it should be. Unfortunately, some of the most egregious manifestations of "degrading treatment" and lack of "respect for dignity" lie in the modus operandi of many Westerners (feminists and others) who have intervened in this matter. The resistance of African women is not against the campaign to end the practice, but against their dehumanization and the lack of dignity and respect shown to them in the process. (Nnaemeka 2005, p. 30; Hale 2005; Korieh 2005)

The core of their critique is that the global feminist movement, instrumental in redefining and promoting women's human rights, has really been a Western rather than a global project. The charge is that the global feminist movement to re-conceptualize women's rights from the lives of women, did so from the lives of particular women, namely

Human Rights Review, Vol. 10, No. 4 (November 2009): pg. 521-530. DOI. This article is (C) Springer and permission has been granted for this version to appear in e-Publications@Marquette. Springer does not grant permission for this article to be further copied/distributed or hosted elsewhere without the express permission from Springer. 
those living in communities of the global North such as the USA and Western Europe. The concept of women's rights as articulated in documents like the Beijing Platform reflect a particular understanding of gender and gender-based oppression, as these are manifested in Western liberal democracies. Specifically, the concept of women's rights presupposes gender dualism, that there are only two genders (i.e., man and woman) and that the root cause of women's oppression is patriarchy, a situation in which men dominate women socially, politically, and economically. These particular interpretations of gender and gender-based oppression coupled with the tendency to focus on gender as the sole or primary axis of oppression for women around the world provides a moral lens that fails to capture accurately the nature of the moral violations and abuses many women suffer and thereby fails to recommend morally appropriate solutions.

Discussions that took place at Beijing were not blind to these concerns and recognized the difficulties in creating and using human rights as a monolithic instrument for addressing gender-specific wrongs because of the difficulty in treating women as a homogenous group or unified category. Nonetheless women's human rights were included in the final draft of the Declaration, and the Platform for Action identified central areas of concern (Guerrina and Zalewski 2007). I turn now to illustrate the problem more precisely by considering the failure of a women's rights-based approach, as it has typically been employed, to produce an adequate moral evaluation of practices of FGC among a particular group of people: the Maasai of Kenya and Tanzania.

\section{Moral Analysis of FGC Among the Maasai}

According to the 1959 UN Convention on the Rights of the Child, each child has a right to "develop physically, mentally, morally, spiritually, and socially in a healthy and normal manner and in conditions of freedom and dignity" (United Nations 1959). Those who advocate a rights-based approach argue that FGC violates a child's right to normal and healthy development in conditions of freedom and dignity because these practices are medically unnecessary, usually extremely painful, disrupt the normal physical and sexual development of the child, and are often performed under coercive conditions in which a child does not have the opportunity to voice opposition to FGC and is not old or mature enough to really understand the procedure

Human Rights Review, Vol. 10, No. 4 (November 2009): pg. 521-530. DOI. This article is (C) Springer and permission has been granted for this version to appear in e-Publications@Marquette. Springer does not grant permission for this article to be further copied/distributed or hosted elsewhere without the express permission from Springer. 
and its potential consequences. The Beijing Platform reaffirms the rights of the child but goes further by focusing explicitly on the rights of the girl child and by identifying FGC as an act of violence against women and girls that constitutes a violation of their rights. The Beijing Platform defines violence against women as "any form of gender-based violence that results in or is likely to result in physical, sexual, or psychological harm."2 Moreover, it states, "Violence against women is a manifestation of the historically unequal power relations between men and women, which have led to domination over and discrimination against women by men and to the prevention of women's full advancement." It locates the source of gender-based violence as deriving "essentially from cultural patterns, in particular the harmful effects of certain traditional or customary practices." 3 Thus, when viewed through the moral lens provided by the Beijing Platform, FGC appears and indeed is labeled as a culturally specific manifestation of patriarchy, an act of violence against women rooted in cultural customs and traditions that aim to preserve male dominance and female subordination.

Because culture and religion are so often used to justify the oppression of women, the triumph of Beijing was to secure a set of gender-specific rights to combat gender-specific wrongs wherever they may be occurring and despite whatever cultural or religious justification might be offered in their defense. One danger, however, is that these rights' standards becomes fixed or static moral starting points for a kind of top-down approach to moral reasoning in the global arena. We start with a particular set of rights, which presuppose that "violence against women is a manifestation of the historically unequal power relations between men and women" that derive "essentially from cultural patterns," and then apply these across a wide variety of contexts in order to identify morally egregious practices that perpetuate this kind of violence. This model of reasoning discourages the idea that a thoroughly historical and cultural analysis of FGC is relevant to a moral analysis of FGC. Instead, we start out "knowing" that these practices constitute human rights violations and even "knowing" their root cause-patriarchy. Contextual details may be invoked at the level of implementation, but they are not typically viewed as relevant to the moral analysis. Yet, the cultural and historical information a top-down approach belies may in fact be vital for an accurate moral evaluation of the practices under scrutiny. In 
order to see, this, I want to offer a culturally and historically laden analysis of FGC as practiced among the Maasai. This analysis of Maasai gender relations reveals that FGC is in fact not best understood as primarily gender-based violence that derives essentially from Maasai cultural patterns. Rather, the link between FGC and the oppression of Maasai women is the product of complex historical interactions between already existing Maasai social relations and a distinctively Western patriarchal ideology imposed on Maasai social life through formal colonization.

The Maasai are primarily pastoralists who make their living by raising and herding cattle. They live on homesteads, practice polygamy, and circumcise both boys and girls at around the same age. Age and gender are the two primary axes of social organization among the Maasai and determine the distribution of roles, rights, and responsibilities in Maasai culture. Anthropologist Dorothy Hodgson notes that, historically, Maasai gender relations were neither dualistic nor hierarchical but were based on notions of complementarity and interdependence. While it is possible to distinguish between a domestic sphere of home and homestead and a public space outside the homestead, these areas were not gendered as primarily female and male. Instead both men and women occupied sections of domestic and public space (Hodgson 1999, 2001). Hodgson likens Maasai social organization to spikes in a bicycle wheel, in which each "category of person, whether young boys or old women, was required to fulfill its responsibilities for livestock and for each other to ensure survival and progress of Maasai households, homesteads, and communities" (Hodgson 1999, p. 50).

For girls, the Maasai practice what the WHO calls type II circumcision or excision, which includes the removal of the clitoris and the labia minora. A girl's circumcision is arranged by her parents usually just after her first menstruation when it is determined that she is ready for marriage and the responsibilities associated with womanhood. The practitioners are elder women, and the ritual involves exclusively women and includes weeks of preparation as girls spend time with their mothers and other elder women learning about the rights and responsibilities that attach to Maasai womanhood. The Maasai believe that circumcision plays an important role in the sexual maturity of a girl by marking the final stage in a gradual process through which a girl becomes a woman. While a "girl" is sexually

Human Rights Review, Vol. 10, No. 4 (November 2009): pg. 521-530. DOI. This article is (C) Springer and permission has been granted for this version to appear in e-Publications@Marquette. Springer does not grant permission for this article to be further copied/distributed or hosted elsewhere without the express permission from Springer 
immature (i.e., literally not yet fertile) and socially unprepared to bear and raise children, a "woman" is fertile, ready for and open to reproduction, and socially equipped to assume the privileges and responsibilities that attach to Maasai womanhood. The Maasai believe that circumcision protects and promotes a woman's fertility and marks the actualization of her biological capacity to reproduce. Yet, importantly, it also indicates a certain level of social responsibility. In an interview with anthropologist Barbara Hoffman, Alice, a Maasai woman, explains that even if a girl has had ten kids, if she has not been circumcised, she will still be considered a child (Hoffman 2002, film).

In the period prior to formal colonization, the social responsibilities associated with Maasai womanhood included a significant amount of economic and political power. Though each homestead belongs to an elder man, each house within a homestead belongs to the woman who built it (Aud Talle 1998, xx, p. 133). Each wife erects her own house according to the order in which she was married, and she controls access to her house, including the access of her husband. As anthropologist Aud Talle notes, occupancy and ownership of a house is a "sign of female maturity and is the base from which female agency is most successfully exercised" (Aud Talle $1998, x x$, p. 133). In a very literal sense, ownership of a house gives a woman authority to act. For example, though male elders were the primary arbiters of community and clan disputes, a married Maasai woman, well established in her home, enjoyed a fair amount of political power, as she was able to initiate and testify at judicial proceedings and often conferred with her husband in resolving disputes both within and between homesteads (Hodgson 1999, p. 48).

As pastoralists, the care and management of livestock is absolutely crucial to community survival, and so perhaps the most significant of all the rights associated with Maasai womanhood were economic rights. While elder men made broad managements decisions about the timing and location of grazing and watering herds and ilmurran (i.e., the young male warrior class) were responsible for guarding the herd from animal attacks or thieves, married women had primary responsibility over livestock products. Once well established in her house, a Maasai woman controlled the production and distribution of milk, which is the primary food staple for the Maasai and plays a crucial role in the ritual life of the community. A Maasai woman milked

Human Rights Review, Vol. 10, No. 4 (November 2009): pg. 521-530. DOI. This article is (C) Springer and permission has been granted for this version to appear in e-Publications@Marquette. Springer does not grant permission for this article to be further copied/distributed or hosted elsewhere without the express permission from Springer. 
her cattle twice a day, kept the milk in gourds to which she alone had access, and then determined the distribution of milk among herself, her children, her husband, visitors, strangers, and even enemies when milk was used to establish a peace agreement. Moreover, Maasai women were also the primary traders in the community traveling to markets outside the homestead in order to barter surplus milk and hides in exchange for other important goods. Husbands and wives also shared overlapping cattle rights deciding together whether to slaughter, trade, or give away an animal (Hodgson 1999, p. 48).

However, only a married woman could own a house and assume the responsibilities and privileges that attach to milk and cattle rights, and only the circumcised are considered women and marriageable. Thus, cultural logic dictated the importance of circumcision in a woman's ability to become a fully participating and relatively powerful member of her community. Despite the rigidly defined social roles for both males and females, however, social relations between the sexes were premised not on domination and subordination but on mutual respect and relative autonomy within those roles. Indeed, Hodgson concludes that "'patriarchal' may be a deeply problematic term by which to characterize Maasai gender relations during this period. Although men, especially elder men, served as primary leaders and arbitrators for their communities, the responsibilities and interactions of men and women were complementary and interdependent" (Hodgson 1999, p. 50).

Gender relations among the Maasai shifted dramatically, however, during and after formal colonization by the British (c. 19201961). The British brought with them assumptions about gendered division of labor in which men were dominant in the public realm of work and political decision making and women were primarily responsible for child rearing and other domestic chores. As Hodgson notes, British authorities "mapped their gender ideologies on to their understandings of and interventions in Maasai life," creating "the male domains of public and political in opposition and superior to the female domains of private and domestic" (Hodgson 1999, p. 57). The colonial policies infused with this ideology, while devastating for all Maasai, were particularly catastrophic for Maasai women. The three most significant colonial policies that altered gender relations among the Maasai were (1) the implementation of indirect rule, (2) the

Human Rights Review, Vol. 10, No. 4 (November 2009): pg. 521-530. DOI. This article is (C) Springer and permission has been granted for this version to appear in e-Publications@Marquette. Springer does not grant permission for this article to be further copied/distributed or hosted elsewhere without the express permission from Springer. 
transformation of a barter economy into a cash economy, and (3) the imposition of a new tax system.

The policy of indirect rule aimed at identifying a central authority to represent the Maasai and to act as an intermediary between the Maasai and British authorities. Assuming that male elders were already "the" political leaders, these policies reshaped Maasai political life by extending the authority of select male elders over both junior men and women, strengthening and consolidating their power. Thus, rather than having political authority somewhat dispersed and at least somewhat shared among Maasai men and women, indirect rule created a centralized male authority and women lost whatever political power they may have previously enjoyed (Hodgson 1999, pp. 53-55). Needing to create a cash economy in order to produce tax revenue for the crown, the British also transformed a previously female-based barter economy into a newly male-dominated cash economy. Livestock was now to be bought and sold on the market for cash. Assuming that males were the "owners" of cattle, Maasai men were integrated into the new economy as buyers and sellers of livestock, while Maasai women were dispossessed from their previously shared cattle rights. Furthermore, women "could generally only gain access to cash indirectly through gifts from men or the sale of cattle by their sons or husbands" and thus went from being primary agents in the Maasai economy to economically dependent on male elders (Hodgson 1999, p. 57). The third policy, which followed directly from the second, was to implement a new system of taxation. This system designated male elders as "tax payers" and "heads of household," who were now required to pay a hut tax or "plural wives" tax for "dependent" women living on their homestead (Hodgson 1999, p. 58). The combined effect of these policies over time was severe material disenfranchisement, political and economic disempowerment, and conceptual devaluation of women. Women went from enjoying at least some political and economic authority and autonomy to being completely dependent on men and, through the system of taxation, to being viewed as property rather than persons (Hodgson 1999, pp. 64-65).

Historically, FGC was linked to significant economic, political, and ritual power for women. Today, the link between FGC and the economic and political roles of Maasai women remains, but the shift in gender relations during formal colonization transformed these into roles of economic and political dependence. This historically and 
contextually rich analysis reveals that FGC among the Maasai is not best understood as a violent manifestation of the historically unequal power relations between Maasai men and women rooted in Maasai cultural patterns that are inherently patriarchal. Rather, the link between FGC and the political and economic disempowerment of Maasai women is in large part the result of historically unequal power relations between all the Maasai and their British colonizers. I do not intend to romanticize or idealize Maasai social relations prior to colonization. Indeed, Hodgson notes that opportunistic Maasai men took advantage of colonial policies in order to strengthen their political and economic power over other men and over women. Rather, the resultant shift in Maasai gender relations and the link between FGC and the oppression of Maasai women is the product of complex interactions between existing Maasai social relations and colonial rule. It is this complexity that document like the Beijing Platform miss and that I contend is crucial for an adequate moral analysis of FGC.

\section{Concluding Thoughts}

I do not mean either to defend practices of FGC or to deny the importance of human rights as tools for moral assessment and political action. Rather, my aim in this paper is to illustrate a fairly significant limitation in the way women's human rights have been constructed and are often used to combat practices of FGC and other genderspecific wrongs. Gender is not static or fixed and does not have a single referent but instead is one axis of social organization that intersects with many others to generate complex systems of oppression for differently situated women. This phenomenon of intersectional oppression is often paid lip service but is not often reflected in processes of moral reasoning and moral discourse that produce what "we" know about FGC or other gender-specific wrongs. If we start our moral analysis with a rights standard that assumes a particular interpretation of gender and gender-based oppression, and then apply this standard to identify and combat gender-specific wrongs in contexts where gender relations do not fit our initial assumptions, then we risk misidentifying the nature of the moral violations under scrutiny and risk implementing ineffective eradication strategies. A more accurate moral analysis of the violence against Maasai women that FGC is said to inflict must include the violence of the historical

Human Rights Review, Vol. 10, No. 4 (November 2009): pg. 521-530. DOI. This article is (C Springer and permission has been granted for this version to appear in e-Publications@Marquette. Springer does not grant permission for this article to be further copied/distributed or hosted elsewhere without the express permission from Springer. 
experience of colonization, for it was a kind of violence, and how this experience contributed to the oppression of Maasai women.

At this point, one might wonder, however, that if the end result is not in dispute, namely that FGC is morally wrong and ought to be stopped, then why does it matter that our moral analysis be contextually and historically sensitive? Or, since colonial policies imposed a distinctively Western patriarchal ideology that did alter gender relations and that now appears to be the root cause of women's oppression around the globe, then why do we need a culturally and historically rich analysis of FGC in order to secure an adequate moral analysis of these practices as they are currently practiced? There are several shortcomings to moral reasoning that targets FGC in abstraction from the particular cultural and historical contexts of the Maasai: A contextually and historically deficient moral analysis of FGC (1) obscures the complexity of Maasai gender relations (e.g., that there are more than two) and, in particular, the ways in which Western notions of gender intersected with Maasai understandings of gender to render the particular forms of oppression Maasai women experience; (2) in so doing, it obscures the significant contribution of international forces, such as colonization, in the oppression of Maasai women; (3) such an analysis risks perpetuating negative stereotypes about African men and women; (4) it risks reinforcing harmful global power dynamics, whereby members of more powerful nations such as the USA and those of Western Europe dominate economically, politically, and militarily also wield epistemic power in international moral discourse; (5) finally, this kind of analysis risks informing ineffective or harmful eradication efforts.

It is these kinds of concerns that Obioma Nnaemeka raises when she claims, "some of the most egregious manifestations of 'degrading treatment' and lack of 'respect for dignity' lie in the modus operandi of many Westerners" who have intervened in discourse surrounding FGC (Nnaemeka 2005, p. 30; Hale 2005; Korieh 2005). The scholars and activists who resist the global feminist discourse surrounding women's human rights are not simply rehashing the universalism/relativism debate. Rather, they are issuing an urgent call for more responsible moral knowledge production at the global level. A more accurate moral analysis of the violence against Maasai women that FGC is said to inflict must include the violence of the historical experience of colonization and how this experience intersects with and

Human Rights Review, Vol. 10, No. 4 (November 2009): pg. 521-530. DOI. This article is (C) Springer and permission has been granted for this version to appear in e-Publications@Marquette. Springer does not grant permission for this article to be further copied/distributed or hosted elsewhere without the express permission from Springer. 
transforms existing gender relations contributing to the oppression of Maasai women.

Political theorist Moira Gatens suggests that we should not conceive of human rights as a "rigid atemporal 'law', nor should cultural norms be seen as incontestable" (Gatens 2004). The global feminist movement has worked hard to ensure the latter, that local cultural and religious norms are not incontestable; yet this approach often fails to acknowledge the former, that human rights need not (and I would say should not) be conceived as atemporal, rigid moral norms. The movement to make women's rights human rights has been the result of moral deliberation among some of the most powerful members of the global community. This does not make them irrelevant to addressing gender-specific wrongs affecting less powerful members of the global order. I think it does mean that rights ought to function as flexible conceptual tools in contextually and historically rich practices of moral reasoning aimed at uncovering complex systems of oppression. Moreover, I think it sets those of us working on moral reasoning in a global context a task of determining how to establish practices of moral reasoning that are more inclusive and that generate more genuinely universal standards for moral assessment. It is strategically important to retain some notion of women's rights, but it is equally important to retain a critical awareness of how women's rights are constructed, who is involved (or not involved in constructing them) and how they are used (or misused) in combating genderspecific wrongs.

\section{Notes}

1. For example, Susan Okin notes that, while slavery is now widely recognized as a human rights violation, the practice of bride selling has rarely been viewed as an instance of slavery. Rather, "if a husband pays a bride price for his wife, or marries her without her adult consent; if he confines her to their home, forbids her to work for pay, or appropriates her wages; if he beats her for disobedience or mishap; these manifestations of slavery would not be recognized as violations of human rights in many parts of the world," but as culturally appropriate behavior that is protected (p. 29).

2. Beijing Platform, p. 59.

3. Ibid, p. 60.

Human Rights Review, Vol. 10, No. 4 (November 2009): pg. 521-530. DOI. This article is (C) Springer and permission has been granted for this version to appear in e-Publications@Marquette. Springer does not grant permission for this article to be further copied/distributed or hosted elsewhere without the express permission from Springer. 
NOT THE PUBLISHED VERSION; this is the author's final, peer-reviewed manuscript. The published version may be accessed by following the link in the citation at the bottom of the page.

\section{References}

Abursharaf Rogaia Mustafa (2006) Introduction: The Custom in Question. In: Abursharaf Rogaia Mustafa (ed) Female Circumcision: Multicultural Perspectives. University of Pennsylvania Press, Philadelphia, PA, p 12 Abusharaf Rogaia Mustafa (2006) Female Circumcision. University of Pennsylvania Press, Philadelphia, PA

Bunch Charlotte (1999) Women's Rights as Human Rights. In: Savic Obrad (ed) The Politics of Human Rights. Verso, France

Covenant for the New Millennium: The Beijing Declaration and Platform for Action, Santa Rosa, CA,Free Hand Books, 1996

Gatens Moira (2004) Can Human Rights Accommodate Women's Rights? Toward an Embodied Account of Social Norms, Social Meaning, and Cultural Change. Contemporary Political Theory 3:288

Guerrina Roberta, Zalewski Marysia (2007) Negotiating Difference/Negotiating Right: The Challenges and Opportunities of Women's Human Rights. Review of International Studies 33:6

Hale Sondra (2005) Colonial Discourse and Ethnographic Residuals: The Female Circumcision Debateand the Politics of Knowledge. In: Nnaemeka Obioma (ed) Female Circumcision and the Politics of Knowledge. Praeger, Westport, CT

Hodgson Dorothy (1999) storalism, Patriarchy, and History: Changing Gender Relations Among Maasai in Tanganyike, 1890-1940. The Journal of African History 40(1)

Hodgson Dorothy (2001) 'Once Intrepid Warriors': Modernity and the Production of Maasai Masculinities. In: Hodgson Dorothy (ed) Gendered Modernities. Palgrave, New York

Hoffman Barbara (2002) "Womanhood and Circumcision: Three Maasai Women have their Say," Berekley Media: Berekley, CA

Korieh Chima (2005) 'Other Bodies': Western Feminism, Race, and Representation in the Female Circumcision Discourse. In: Nnaemeka Obioma (ed) Female Circumcision and the Politics of Knowledge. Praeger, Westport, CT

Morgan Robin (1984) Sisterhood if Global. Garden City Press, New York Nnaemeka Obioma (2005) African Women, Colonial Discourses, and Imperialist Interventions: Female Circumcision as Impetus. In: Nnaemeka Obioma (ed) Female Circumcision and the Politics of Knowledge. Praeger, Westport, CT, p 30

Okin Susan (1998) Feminism, Women's Human Rights, and Cultural Differences. In: Narayan Uma, Harding Sandra (eds) Decentering the Center. Indiana University Press, Bloomington, IN, p 28

Okin Susan (1999) Is Multiculturalism Bad for Women. Princeton University Press, Princeton, NJ

Human Rights Review, Vol. 10, No. 4 (November 2009): pg. 521-530. DOI. This article is (C) Springer and permission has been granted for this version to appear in e-Publications@Marquette. Springer does not grant permission for this article to be further copied/distributed or hosted elsewhere without the express permission from Springer. 
NOT THE PUBLISHED VERSION; this is the author's final, peer-reviewed manuscript. The published version may be accessed by following the link in the citation at the bottom of the page.

Peters Julie, Wolper Andrea (1995) Women's Rights, Human Rights: Inernational Feminist Perspectives. Routledge, New York, NY

Talle Aud (1998) Female and male in Maasai life: aging and fertility. In: Mario I. Aguilar (ed) The Politics of Age and Gerontocracy in Africa: Ethnographies of the Past. Africa World Press

United Nations (1959) United Nations Declaration on the Rights of the Child, Principle 2, at http://www. unhchr.ch/html/menu3/b/25.htm. 